\title{
PHOSPHATIDIC ACID AND PHOSPHOLIPASE D BOTH STIMULATE PHOSPHOINOSITIDE TURNOVER IN CULTURED HUMAN KERATINOCYTES
}

\author{
NeIl S. Ryder, * Harvinder S. Talwar, Nicholas J. Reynolds, John J. Voorhees and \\ GARY J. FISHER \\ Department of Dermatology, University of Michigan Medical Center, Ann Arbor, MI 48109, U.S.A.
}

(Received 18 May 1993; and accepted 30 May 1993)

\begin{abstract}
Phosphatidic acid (PA) induced a rapid dose-dependent increase in production of inositol phosphates in cultured adult human keratinocytes, peaking at $30 \mathrm{~s}$. Natural and dioleoyl PA were equally effective, while other phospholipid classes had no effect. Lipid A was also active. Lyso-PA also induced inositol phosphate production, but contamination of the PA preparation by lyso-PA could not account for the effect of PA. The effect of PA could not be reproduced by treatment of cells with calcium ionophore. PA-induced inositol phosphate production could be inhibited $(>50 \%)$ by pre-treatment of cells with either pertussis toxin or 12-O-tetradecanoylphorbol 13-acetate, suggesting the involvement of a GTP-binding protein and a protein kinase $\mathrm{C}$-mediated negative feedback mechanism. PA also stimulated release of arachidonic acid from keratinocytes. Treatment of cells with exogenous phospholipase D similarly induced inositol phosphate production in the keratinocytes. Since PA may be formed by receptor-mediated activation of phospholipase D, or by phosphorylation of diacylglycerol, the results suggest that PA may play a significant role in signalling mechanisms of human keratinocytes.
\end{abstract}

Key words: Phosphatidic acid, keratinocytes, phospholipase D, arachidonate, phospholipids, inositol phosphates, signal transduction.

\section{INTRODUCTION}

PhosPHATIDIC acid (PA) is rapidly produced in a variety of cells after stimulation by calciummobilizing hormones, growth factors and neurotransmitters [1-11]. It is formed during receptor-mediated activation of the phosphoinositide cycle $[1,12]$ in which phospholipase $C$ hydrolyses PtdIns(4,5) $\mathrm{P}_{2}$ forming two intracellular second messengers, inositol trisphosphate $\left(\operatorname{Ins}(1,4,5) \mathrm{P}_{3}\right)$ and 1,2-diacylglycerol (DAG). The Ins $(1,4,5) \mathrm{P}_{3}$ induces an increase in intracellular free calcium concentration [13] while DAG directly activates protein kinase $\mathrm{C}$

\footnotetext{
* Permanent address for correspondence: Dermatology Department, Sandoz Research Institute, Brunnerstrasse 59, A-1235 Vienna, Austria.

Abbreviations: PA-phosphatidic acid; PtdIns(4,5) $\mathrm{P}_{2}-$ phosphatidylinositol $(4,5)$ bisphosphate; Ins $(1,4,5) \mathrm{P}_{3}$-inositol $(1,4,5)$ bisphosphate; LPA-lysophosphatidic acid; DAG-1,2-diacylglycerol; KGM, keratinocyte growth medium, KBM-keratinocyte basal medium.
}

[14]. The DAG is rapidly removed by phosphorylation to give PA. Hokin-Neaverson et al. [6] first suggested that PA might also be produced directly from PtdIns by the action of a phospholipase $\mathrm{D}$, and receptor-mediated activation of phospholipase $D$ has now been reported in various cell types [7, 9, 15]. A further potential source of intracellular PA is by de novo phospholipid biosynthesis, as shown in the case of myocytes stimulated with insulin [8]. Subsequent to its formation, PA may be recycled back to PtdIns or may under some circumstances be dephosphorylated to form DAG [8]. Apart from this role in phosphoinositide metabolism, relatively little is known about the intracellular functions of PA. In platelets, PA may serve as a source of arachidonate after breakdown by a specific phospholipase $A_{2}$ [2]. Exogenously applied PA has been reported to stimulate calcium influx and calcium-mediated processes in various cell types 
[16-19]. The effects of PA on cells were previously explained by its ability to mobilize extracellular calcium by an ionophore effect [17-20]. More recently, however, PA has been found to stimulate phosphoinositide turnover in various cells including fibroblasts [21], A431 cells [22], human mesangial cells [23] and myocytes [24], thereby leading to release of intracellular calcium reserves. Both PA and lysophosphatidic acid (LPA) have also been reported to have mitogenic and growth factorlike properties [22, 25-28], although the relationship of this to phosphoinositide turnover is not clear. It thus appears that PA acts both as an agonist for, and as a key intermediate within, the phospholipase-linked signalling pathways leading to activation of protein kinase $\mathrm{C}$.

The mechanism of this pathway in the skin is of considerable interest with respect to its potential involvement in the pathogenesis of inflammatory and hyperproliferative skin diseases such as psoriasis. Psoriatic epidermis shows abnormalities in several components of this system, including protein kinase $C[29,30]$, phospholipase C [31, 32] and PtdIns kinase [33]. Several inflammatory mediators have been shown to activate phospholipase $\mathrm{C}$ in human epidermal cells (keratinocytes) [34-36]. In this paper, we demonstrate that both PA and treatment with exogenous phospholipase $\mathrm{D}$ activate phosphoinositide turnover in human keratinocytes, leading to release of arachidonate-derived products; possible implications for signal mechanisms in these cells are also discussed.

\section{MATERIALS AND METHODS}

\section{Materials}

Keratinocyte growth medium (KGM, serum-free, low calcium) and basal medium (KBM, free from growth factors) were supplied by Clonetics Inc. (San Diego). Radiochemicals were obtained from New England Nuclear and biochemicals from Sigma unless otherwise stated. Pertussis toxin was from List Biochemicals (Campbell, California). Anion exchange resin Dowex AG 1-X8 (formate form) was from BioRad Laboratories. Phosphatidic acid (Sigma P 9511) was stored as a chloroform solution (1 $\mathrm{mg} / \mathrm{ml}$ ). Immediately before use, the required quantity was dried under a stream of nitrogen and redissolved in $150 \mathrm{mM} \mathrm{NaCl}$ with the aid of an ultrasonic bath. Other lipids for testing were prepared in a similar manner.

\section{Analysis of $P A$}

The PA used in these experiments was analysed for the presence of LPA, which has been reported to be a significant contaminant of commercially available PA [37]. Samples of PA $(100,200$ and $300 \mu \mathrm{g})$ and LPA $(0.1-10 \mu \mathrm{g})$ were spotted onto high performance thin layer plates (Whatman) and run in chloroform/ methanol/acetic acid/water (75:95:12:3). The plates were air dried for $10 \mathrm{~min}$, sprayed with $10 \%$ cupric sulphate in $8 \%$ phosphoric acid, then heated for 5 min at $120^{\circ} \mathrm{C}$, and for $10 \mathrm{~min}$ at $170^{\circ} \mathrm{C} \mathrm{[38].} \mathrm{After}$ cooling, plates were scanned with an Ultrascan laser densitometer (LKB) connected to a Hewlett-Packard integrator. The amounts of LPA in the PA samples were determined from a standard curve of peak area versus LPA standard. The PA $(100 \mu \mathrm{g})$ was found to contain $0.63 \pm 0.1 \mu \mathrm{g}$ LPA (average of five determinations), equivalent on a molar basis to $1.12 \%$ contamination (using $M_{r} \mathrm{PA}=775$, $\mathrm{LPA}=434$ ).

\section{Keratinocyte culture}

Keratinocyte cultures were established from normal adult human keratome biopsies and maintained in KGM medium as described previously [34]. Cells were used between passages 2 and 6 .

\section{Measurement of inositol phosphates}

Keratinocytes were grown to $70 \%$ confluency in 35-mm dishes. The medium was then changed to inositol-free KBM and the cells labelled with $\left[{ }^{3} \mathrm{H}\right]$ myo-inositol $(1 \mu \mathrm{Ci} / \mathrm{ml})$ for $48 \mathrm{~h}$. The cultures were cooled on ice and washed with phosphatebuffered saline. The medium was replaced with KBM $(0.8 \mathrm{ml} /$ dish) containing $20 \mathrm{mM} \mathrm{LiCl}$ and the dishes pre-incubated $10 \mathrm{~min}$ at $37^{\circ} \mathrm{C}$. The agonist to be tested $(8 \mu \mathrm{l})$ was added and the incubation continued for the times stated. Reactions were stopped by addition of $1 \mathrm{ml}$ ice-cold methanol containing $1 \%$ concentrated $\mathrm{HCl}$. Cells were scraped from the dishes, and the inositol phosphate and phospholipid fractions were separated as described previously [34]. The individual $\left[{ }^{3} \mathrm{H}\right]$ inositol phosphates were fractionated by ion exchange chromatography on $1 \mathrm{ml}$ columns by the method of Berridge et al. [39], and counted for radioactivity.

\section{Measurement of arachidonate release}

Keratinocytes were grown to $80 \%$ confluency in $35-\mathrm{mm}$ dishes and then labelled with $\left[{ }^{3} \mathrm{H}\right]$ arachidonic 
acid $(0.5 \mu \mathrm{Ci} / \mathrm{ml})$ for $16 \mathrm{~h}$ in $\mathrm{KBM}$ medium $(1 \mathrm{ml} /$ dish). Cells were washed to remove excess radioactivity and the medium replaced with $1 \mathrm{ml}$ fresh KBM containing bovine serum albumin $(1 \mathrm{mg} / \mathrm{ml})$. Incubations were started by addition of PA $(10 \mu \mathrm{g} /$ $\mathrm{ml}$ ) and were carried out at $37^{\circ} \mathrm{C}$ in the $\mathrm{CO}_{2}$ incubator. At the required time, $0.5 \mathrm{ml}$ supernatant was carefully removed and extracted by addition of $1 \mathrm{ml}$ chloroform $/ \mathrm{methanol} / \mathrm{HCl}$ (1:1:0.003). The chloroform phase was transferred to a scintillation vial, dried under nitrogen and counted for radioactivity.

\section{General}

Experiments were performed with triplicate or quadruplicate dishes of cells for each treatment. Results given are from typical experiments repeated at least twice with consistent results. Statistical significance was established by analysis of variance followed by multiple $t$-test.

\section{RESULTS AND DISCUSSION}

Time and dose dependence of PA-induced accumulation of inositol phosphates

Addition of PA $(10 \mu \mathrm{g} / \mathrm{ml}, 12.9 \mu \mathrm{M})$ to human keratinocytes prelabelled with $\left[{ }^{3} \mathrm{H}\right] \mathrm{Ins}$ led to rapid accumulation of $\left[{ }^{3} \mathrm{H}\right] \mathrm{InsP}_{3}$, reaching a maximum after $30 \mathrm{~s}$ and remaining elevated for at least $8 \mathrm{~min}$ (Fig. 1). Similar kinetics were observed for alterations in InsP $P_{2}$. After a short lag period, a steady accumulation of InsP occurred throughout the $8 \mathrm{~min}$ incubation period. This presumably was due at least in part to dephosphorylation of inositol polyphosphates, the breakdown of InsP being prevented by the presence of $20 \mathrm{mM} \mathrm{LiCl}$. A similar stimulation of inositol phosphate production by PA $(10 \mu \mathrm{g} / \mathrm{ml})$ was found in human dermal fibroblasts (data not shown) as has previously been reported in 3T3 fibroblasts [21]. The effect of PA in keratinocytes was dose-dependent in the range $0.1-100 \mu \mathrm{g} / \mathrm{ml}$ (Fig. 2) and did not appear to be fully saturated at the uppermost concentration (equivalent to about $0.13 \mathrm{mM}$ ). This relatively high concentration of PA is in agreement with concentrations reported to have mitogenic and phospholipase $\mathrm{C}$ stimulating activity in other cell types $[21,22,26]$.

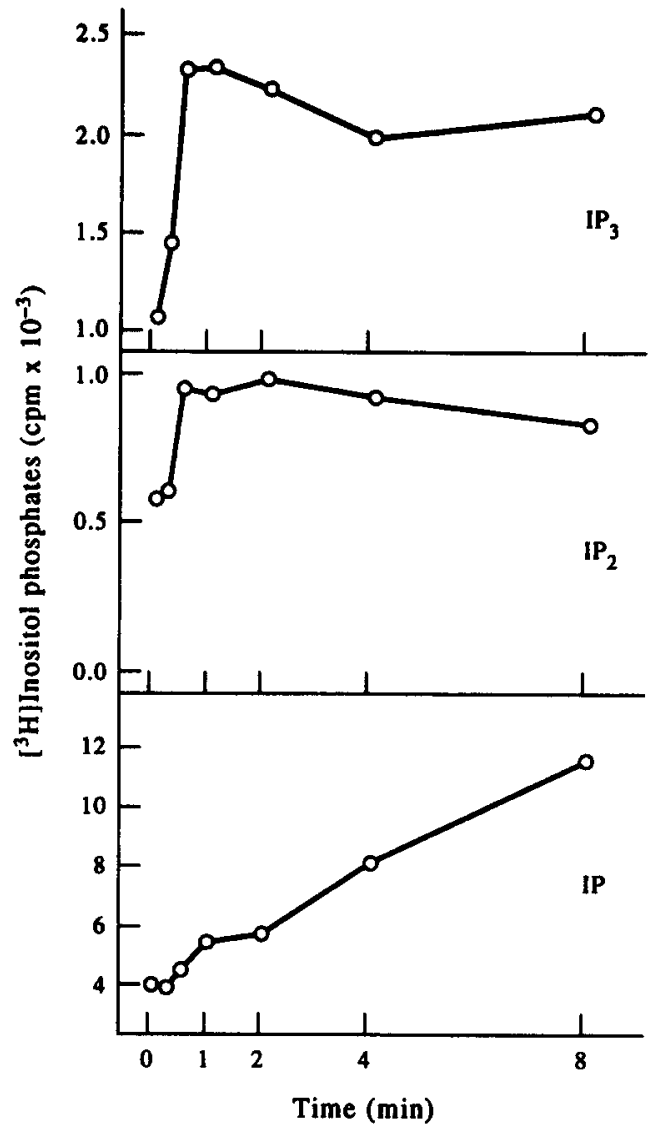

Fig. 1. Time course of PA-induced stimulation of $\left[{ }^{3} \mathrm{H}\right]$ inositol phosphate production in human keratinocytes. Concentration of PA was $10 \mu \mathrm{g} / \mathrm{ml}$. Each point is the mean of values derived from three separate dishes of cells.

\section{Specificity of PA-induced formation of inositol phosphates}

Natural PA (with mixed acyl chains, commonly 1-stearoyl,2-arachidonoyl) was used for most experiments described here, but synthetic dioleoyl PA was equally effective in stimulating $\left[{ }^{3} \mathrm{H}\right]$ inositol phosphate production (Table 1). The effect was specific for PA and was not elicited by other phospholipids such as phosphatidylserine and phosphatidylcholine. Bacterial lipid A, which has structural similarities to PA, gave a weak but significant response while lipopolysaccharide was completely ineffective (Table 1). This is in contrast 


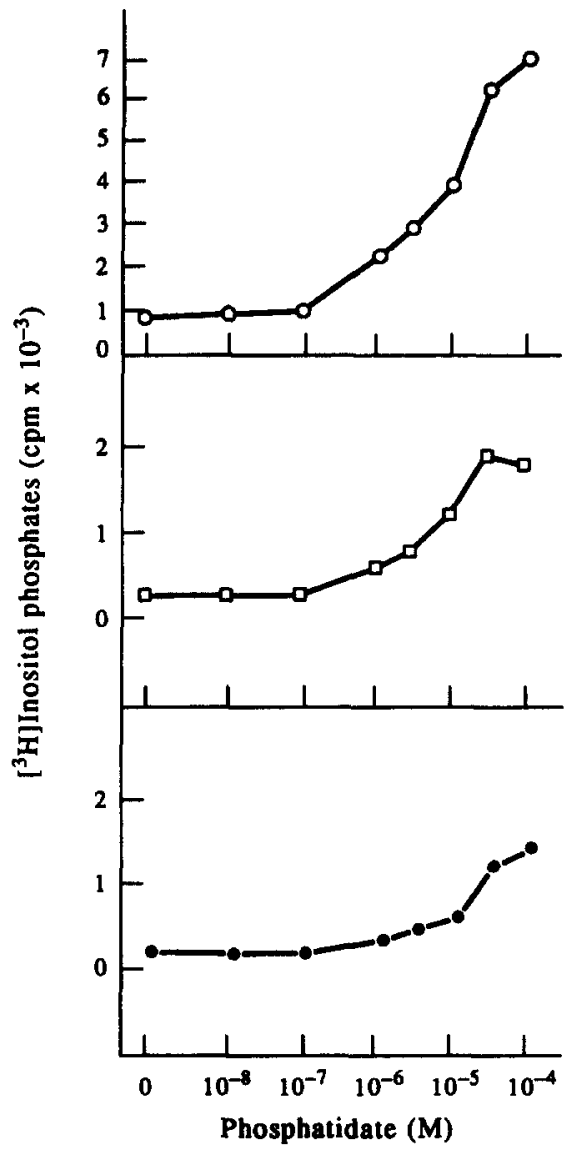

Fig. 2. Dose dependence of PA-induced stimulation of $\left[{ }^{3} \mathrm{H}\right]$ inositol phosphate production in human keratinocytes. Time of incubation with PA was $4 \mathrm{~min}$. Each point is mean of values derived from three separate dishes of cells. Symbols: (O) InsP; ( $\square$ ) InsP $\mathbf{P}_{2} ;(\mathrm{O})$ InsP $_{3}$.

to the findings of Jackowski and Rock [40], in which the more soluble lipopolysaccharide was much more effective than lipid $\mathbf{A}$ as an activator of PtdIns $(4,5) \mathrm{P}_{2}$ hydrolysis in human platelet membrane preparations. The lack of effect of lipopolysaccharide in the keratinocytes may have been due to failure to gain access to the receptor/phospholipase $\mathbf{C}$ system in intact cells.

It has been suggested that the calcium-mobilizing action and possibly other biological activities of PA are actually caused by contaminating traces of LPA which occur in commercial PA preparations [37]. We therefore analysed the PA used in these investigations, as described in Materials and Methods, and found contamination by $1.1 \%$ LPA on a molar basis. The potential contribution of this LPA to the results with PA was assessed in a direct comparison of the two compounds (Table 2). On the basis of the analysis, experiments using PA at $10 \mu \mathrm{g} / \mathrm{ml}(12.9 \mu \mathrm{M})$ or $100 \mu \mathrm{g} / \mathrm{ml}(129 \mu \mathrm{M})$ contained $0.14 \mu \mathrm{M}$ or $1.4 \mu \mathrm{M}$ LPA, respectively. At $1.29 \mu \mathrm{M}$, LPA had no effect on levels of InsP $P_{2}$ and InsP ${ }_{3}$ but stimulated InsP formation by $36 \%$ (Table 2 ). Therefore, only at the highest PA concentration tested $(100 \mu \mathrm{g} / \mathrm{ml}, 129$ $\mu \mathrm{M})$ could contaminating LPA have made any contribution (maximum of a few per cent) to measured levels of $\operatorname{InsP}_{3}$ and InsP $\mathrm{P}_{2}$, although some effect on InsP (maximum 36\%) is possible. We conclude that contaminating LPA did not significantly contribute to the effects of PA in the experiments described here. From Table 2, it is clear that LPA was a more potent stimulator of phosphoinositide turnover than was PA. PA and LPA were reported to have equal mitogenic potency in fibroblasts [28], but these two lipids appear to have some divergent biochemical activities: LPA, but not PA, raised intracellular calcium levels in fibroblasts [37], while PA, but not LPA, was found to activate phosphatidylinositol-4-phosphate kinase [41].

\section{Mechanism of action of $P A$}

Treatment of keratinocytes with a calcium ionophore caused less than $40 \%$ stimulation of inositol phosphate production in comparison with controls (Table 1), which was slight in comparison with PA ( $>200 \%$ stimulation). Thus, the previously suggested ionophore activity of PA [17-20] would not explain the stimulatory effect of PA observed in these experiments. Evidence from this and previous work $[21,22]$ indicates rather that the action of PA is due to its interaction with a receptor/ phospholipase C system.

Activation of keratinocyte $\left[{ }^{3} \mathrm{H}\right]$ inositol phosphate production by PA was partially inhibited (about $50 \%$ ) by pre-treatment of the cells with pertussis toxin (Table 3). Pertussis toxin inacti- 
TABle 1. EFFect of PA AND OTHER LIPIDS ON PRODUCTION OF [ $\left.{ }^{3} \mathrm{H}\right]$ INOSITOL PHOSPHATES IN HUMAN KERATINOCYTES

\begin{tabular}{lrcc}
\hline Treatment & $\begin{array}{c}\text { InsP } \\
(\text { kc.p.m. }\end{array}$ & $\begin{array}{c}\text { InsP } \\
\text { (kc.p.m.) }\end{array}$ & $\begin{array}{c}\text { InsP } \\
\text { (kc.p.m.) }\end{array}$ \\
\hline Control & $6.19 \pm 0.70$ & $1.17 \pm 0.12$ & $1.17 \pm 0.11$ \\
PA $(10 \mu \mathrm{g} / \mathrm{ml})$ & $19.78 \pm 0.68$ & $2.67 \pm 0.28$ & $3.90 \pm 0.28^{*}$ \\
PA dioleyl $(10 \mu \mathrm{g} / \mathrm{ml})$ & $22.41 \pm 2.01$ & $2.89 \pm 0.58$ & $3.88 \pm 0.43^{*}$ \\
Phosphatidyl serine $(10 \mu \mathrm{g} / \mathrm{ml})$ & $6.81 \pm 1.87$ & $1.24 \pm 0.06$ & $1.24 \pm 0.15$ \\
Phosphatidyl choline $(10 \mu \mathrm{g} / \mathrm{ml})$ & $7.65 \pm 1.27$ & $1.32 \pm 0.06$ & $1.40 \pm 0.01$ \\
Lipid A $(10 \mu \mathrm{g} / \mathrm{ml})$ & $9.54 \pm 2.88$ & $1.41 \pm 0.35$ & $3.04 \pm 0.62^{*}$ \\
LPS $(5 \mu \mathrm{g} / \mathrm{ml})$ & $4.97 \pm 0.46$ & $0.98 \pm 0.08$ & $1.12 \pm 0.06$ \\
Ionomycin $(3 \mu \mathrm{M})$ & $8.53 \pm 1.70$ & $1.43 \pm 0.11$ & $1.64 \pm 0.32^{*}$ \\
\hline
\end{tabular}

Cells were labelled for $48 \mathrm{~h}$ with $\left[{ }^{3} \mathrm{H}\right]$ inositol, washed and incubated with lipids as described in the text. After $4 \mathrm{~min}$ the incubations were stopped and the $\left[{ }^{3} \mathrm{H}\right]$ inositol phosphates extracted, separated by ion exchange chromatography and counted for radioactivity. Values are given as mean \pm S.D. for three separate dishes of cells

*Indicates that the value for total inositol phosphates is significantly different from that of the control $(P<0.05)$.

vates the Gi family of GTP-binding proteins by ADP-ribosylation of their alpha subunit [42], suggesting the involvement of such a protein linking phospholipase $\mathrm{C}$ to a putative receptor for PA. When applied to keratinocytes without pre-incubation, pertussis toxin had no immediate agonist or inhibitory effect on inositol phosphate production (data not shown). Pre-treatment of the cells with phorbol 12myristate 13-acetate also partially eliminated the PA-induced response (Table 3), suggesting the operation of a protein kinase C-mediated feedback inhibitory loop. This type of control mechanism is thought to act by disrupting the link between the GTP-binding protein and the phospholipase $C$ [9]. These findings are consistent with a role for PA as an agonist of receptor-mediated phospholipase $\mathrm{C}$ activation. Murayama and Ui [27] have proposed the existence of specific membrane receptors for PA. However, a mechanism for efficient uptake of extracellular PA has been demonstrated [43] and PA could also act directly within the cell membrane, perhaps by altering the lipid micro-

Table 2. Comparison of PA and LPA as stimulators of $\left[{ }^{3} \mathrm{H}\right]$-InOsitol PHOSPHATE PRODUCTION

\begin{tabular}{lcccc}
\hline Lipid & $\begin{array}{c}\text { Conc. } \\
(\mu \mathrm{M})\end{array}$ & $\begin{array}{c}\text { InsP } \\
(\text { kc.p.m. })\end{array}$ & $\begin{array}{c}\text { InsP } \\
(\text { kc.p.m. })\end{array}$ & $\begin{array}{c}\text { InsP }_{3} \\
(\text { kc.p.m. }\end{array}$ \\
\hline Control & & $7942 \pm 1186$ & $1485 \pm 324$ & $1037 \pm 51$ \\
PA & 1.29 & $9949 \pm 407$ & $1510 \pm 54$ & $705 \pm 147$ \\
PA & 12.9 & $11,822 \pm 1370$ & $2271 \pm 188$ & $1239 \pm 139$ \\
PA & 129 & $19,064 \pm 489$ & $6034 \pm 275$ & $3438 \pm 732$ \\
LPA & $1.29 *$ & $10,800 \pm 667$ & $1180 \pm 56$ & $778 \pm 113$ \\
LPA & 12.9 & $12,077 \pm 854$ & $1365 \pm 221$ & $2370 \pm 549$ \\
LPA & 129 & $18,050 \pm 1286$ & $6420 \pm 893$ & $6283 \pm 773$ \\
\hline
\end{tabular}

Experiment performed as in Table 1.

*The level of LPA present in $115 \mu \mathrm{M}$ PA. 


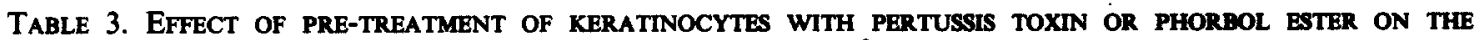
PHOSPHATIDATE-INDUCED PRODUCTION OF [ ${ }^{3} \mathrm{H}$ ] INOSTTOL PHOSPHATES

\begin{tabular}{lcccccc}
\hline Pre-treatment & PA & $\begin{array}{c}\text { InsP } \\
\text { (kc.p.m.) }\end{array}$ & $\begin{array}{c}\text { InsP } \\
\text { (kc.p.m.) }\end{array}$ & $\begin{array}{c}\text { InsP } \\
\text { (kc.p.m.) }\end{array}$ & $\begin{array}{c}\text { Stim.* } \\
\text { by PA }\end{array}$ & $\begin{array}{c}\text { Inhib. } \\
(\%)\end{array}$ \\
\hline Control & - & $7.41 \pm 2.49$ & $0.97 \pm 0.10$ & $2.21 \pm 0.91$ & & \\
Control & + & $22.27 \pm 3.30$ & $2.53 \pm 0.16$ & $7.57 \pm 0.91$ & $3.1 \dagger$ & \\
PMA & - & $4.17 \pm 1.06$ & $0.69 \pm 0.05$ & $1.63 \pm 0.30$ & & 52 \\
PMA & + & $6.19 \pm 0.31$ & $0.79 \pm 0.09$ & $2.51 \pm \mathbf{0 . 1 8}$ & $1.5 \dagger$ & \\
P.T. & - & $7.39 \pm 1.65$ & $0.77 \pm 0.11$ & $2.45 \pm 0.61$ & & 52 \\
P.T. & + & $10.15 \pm 2.74$ & $1.25 \pm 0.22$ & $4.12 \pm 0.82$ & 1.5 & 52 \\
\hline
\end{tabular}

Cells were labelled for $48 \mathrm{~h}$ with $\left[{ }^{3} \mathrm{H}\right]$ inositol as described, then pre-treated either with pertussis toxin (P.T.; $0.4 \mu \mathrm{g} / \mathrm{ml}, 3.5 \mathrm{~h}$ ) or with phorbol 12-myristrate 13-acetate (PMA; $50 \mathrm{mM}, 20 \mathrm{~min}$ ). Cells were then washed, stimulated with PA $(10 \mu \mathrm{g} / \mathrm{ml}, 4 \mathrm{~min})$ and the $\left[{ }^{3} \mathrm{H}\right]$ inositol phosphates determined as described in the text. Values are given as mean \pm S.D. for three separate dishes of cells.

*Degree of stimulation by PA (fold increase in total inositol phosphates).

†Indicates that this total is significantly greater than that of the respective control group, with $P<0.05$.

$\ddagger$ Inhibition (resulting from pre-treatment) of stimulation, in comparison with non-pretreated controls.

environment of the phospholipase $\mathrm{C}$ and/or its associated GTP-binding proteins. PA has recently been reported to cause direct activation of a solubilized phospholipase $C$ from platelet membranes [40] and of phospholipase $C \gamma 1$ [44].

\section{Arachidonic acid release}

Treatment with PA induced a rapid timedependent release of radioactivity from keratinocytes pre-labelled with $\left[{ }^{3} \mathrm{H}\right]$ arachidonate (Fig. 3) suggesting that activation of a phospholipase $A_{2}$ may be one result of the signal pathway initiated by PA. Activation of phospholipase $A_{2}$ by PA in platelets has recently been reported [45]. Several other phospholipase $C$ agonists have also been found to induce arachidonate release in keratinocytes $[35,46,47]$.

Stimulation of formation of inositol phosphates by phospholipase $D$ treatment

Since PA is itself a product of receptor activation, we examined the effects of endogenous PA formation in the keratinocyte membranes. This was achieved by treating the cells with exogenous phospholipase $D$, which cleaves phospholipids to form PA and the respective head group. This treatment also led to stimulation of inositol phosphate produc- tion, the effect being somewhat slower than that induced by direct application of PA (Fig. 4), as might be expected from the progressive formation of the agonist by enzyme action. The stimulatory effect of phospholipase $D$ and of PA is particularly interesting in the light of evidence from several different cell types that phospholipase $D$ is directly involved in signal

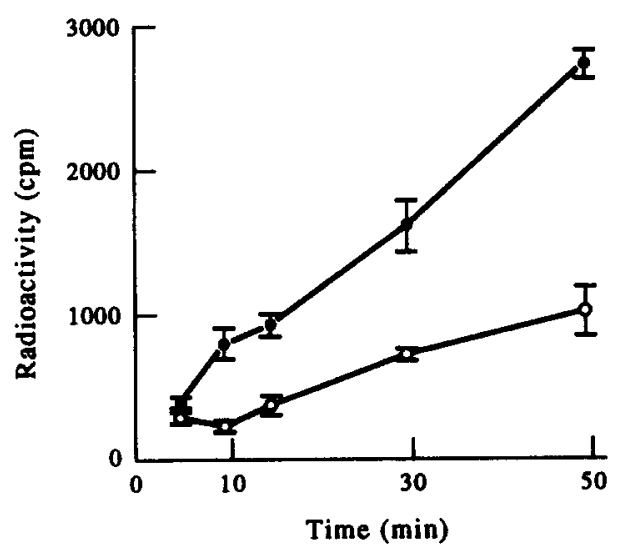

Fig. 3. Time course of PA-induced $\left[{ }^{3} \mathrm{H}\right]$ arachidonate release from human keratinocytes. Cells were labelled for $16 \mathrm{~h}$ with $\left[{ }^{3} \mathrm{H}\right]$ arachidonate, washed and incubated (O) with PA $(10 \mathrm{mg} / 1)$, or $(O)$ without PA. Samples of the cell supernatant were counted for radioactivity. Each point is mean of values derived from three separate dishes of cells. 


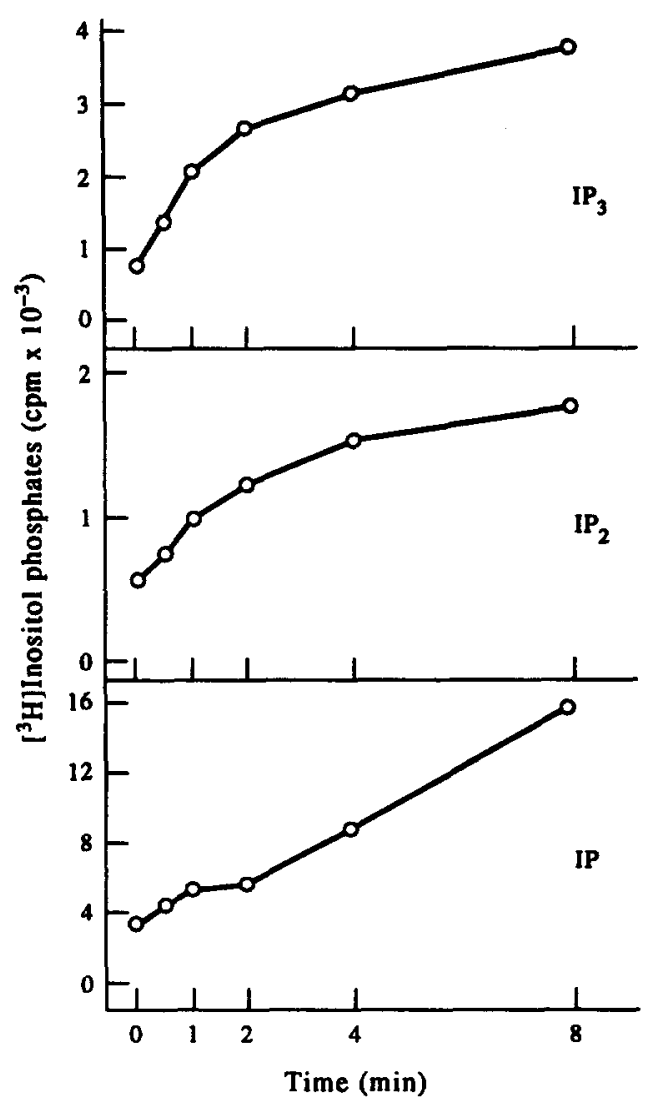

Fig. 4. Time course of $\left[{ }^{3} \mathrm{H}\right]$ inositol phosphate production in keratinocytes treated with phospholipase D (Sigma P8023, $100 \mathrm{U} / \mathrm{ml}$ ). Each point is mean of values derived from four separate dishes of cells.

transduction. Receptor-mediated activation of phospholipase $\mathrm{D}$ may lead to second messenger formation by cleavage of phosphatidylinositol, phosphatidylethanolamine or, most commonly, phosphatidylcholine [15]. The PA formed may be further metabolized to DAG by sequential action of PA phosphatase. However, the available evidence indicates that PA may function as an important second messenger in its own right, mediating a variety of physiological signals [15, 48,49 ] and providing a mechanism for signal bifurcation and/or amplification. The present data suggest that PA has such a function in human keratinocytes, leading to activation of the phosphoinositide and eicosanoid pathways.

\section{REFERENCES}

1. Michell R. H. (1975) Biochim. biophys. Acta 415, 81-147.

2. Lapetina E. G., Billah M. M. and Cuatrecasas P. (1981) Nature 292, 367-369.

3. Thomas A. P., Marks J. S., Coll K. E. and Williamson J. R. (1983) J. biol. Chem. 258, 5716-5725.

4. Takenawa T., Homma Y. and Nagai Y. (1982) Biochem. Pharmac. 31, 2663-2667.

5. Salmon D. M. and Honeyman T. W. (1980) Nature 284, 344-345.

6. Hokin-Neaverson M., Sadeghian K., Majumber A. L. and Eisenberg F. Jr. (1975) Biochem. biophys. Res. Commun. 67, 1537-1544.

7. Cockcroft S. (1984) Biochim. biophys. Acta 795, $37-46$.

8. Farese R. V., Konda T. S., Davis J. S., Standaert M. L., Pollet R. J. and Cooper, D. R. (1987) Science 236, 586-589.

9. Bocckino S. B., Blackmore P. F., Wilson P. B. and Exton J. H. (1987) J. biol. Chem. 262, 15309-15315.

10. Billah M. M., Pai J. K., Mullmann T. J., Egan R. W. and Siegel M. I. (1989) J. biol. Chem. 264, 9069-9076.

11. Fisher G. J., Henderson P. A., Voorhees J. J. and Baldassare J. J. (1991) J. Cell Physiol. 146, 309-317.

12. Irvine R. F. (1992) Curr. Opinion Cell Biol. 4, 212-219.

13. Berridge M. J. and Irvine R. F. (1984) Nature 312, 315-321.

14. Kishimoto A., Takai Y., Mori T., Kikkawa U. and Nishizuka Y. (1980) J. biol. Chem. 255, 2273-2276.

15. Billah M. M. (1993) Curr. Opinion Immun. 5, 114-123.

16. Altin J. G. and Bygrave F. L. (1987) Biochem. J. 247, 613-619.

17. Barritt G. J., Dalton K. A. and Whiting J. A. (1981) FEBS Lett. 125, 137-140.

18. Harris R. A., Schmidt J., Hitzemann B. A. and Hitzemann R. J. (1981) Science 212, 1290-1291.

19. Ohsako S. and Deguchi T. (1983) FEBS Lett. 152, 62-66.

20. Tyson C. A., Zande H. V. and Green D. E. (1976) J. biol. Chem. 251, 1326-1332.

21. Murayama T. and Ui M. (1987) J. biol. Chem. 262, 12463-12467.

22. Moolenaar W. H., Kruijer W., Tilly B. C., Verlaan I., Bierman A. J. and de Laat S. W. (1986) Nature 323, 171-173.

23. Knauss T. C., Jaffer F. E. and Abboud H. E. (1990) J. biol. Chem. 265, 14457-14463.

24. Kurz T., Wolf R. A. and Corr P. B. (1993) Circ. Res. 72, 701-706. 
25. Siegmann D. W. (1987) Biochem. biophys. Res. Commun. 145, 228-233.

26. Yu C.-L., Tsai M.-H. and Stacey D. W. (1988) Cell 52, 63-71.

27. Murayama T. and Ui M. (1987) J. biol. Chem. 262, 5522-5529.

28. van Corven E. J., van Rijswijk A., Jalink K., van der Bend R. L., van Blitterswijk W. J. and Moolenaar W. H. (1992) Biochem. J. 281, 163-169.

29. Horn F., Marks F., Fisher G. J., Marcelo C. L. and Voorhees J. J. (1987) J. Invest. Dermatol. 88, 220-222.

30. Nagao S., Seishima M., Mori S. and Nozawa Y. (1988) J. Invest. Dermatol. 90, 406-408.

31. Bartel R. L., Marcelo C. L. and Voorhees J. J. (1987) J. Invest. Dermatol. 88, 447-451.

32. Fisher G. J., Talwar H. S., Baldassare J. J., Henderson P. and Voorhees J. J. (1990) J. Invest. Dermatol. 95, 428-435.

33. Pike M. C., Lee C. S., Elder J. T., Voorhees J. J. and Fisher G. J. (1989) J. Invest. Dermatol. 92 , 791-797.

34. Talwar H. S., Fisher G. J., Harris V. A. and Voorhees J. J. (1989) J. Invest. Dermatol. 93, 241-245.

35. Fisher G. J., Talwar H. S., Ryder N. S. and Voorhees J. J. (1989) Biochem. biophys. Res. Commun. 163, 1344-1350.

36. Talwar H. S., Fisher G. J. and Voorhees J. J. (1990) J. Invest. Dermatol. 95, 705-710.
37. Jalink K., van Corven E. J. and Moolenaar W. H. (1990) J. biol. Chem. 265, 12232-12239.

38. Touchstone J. C., Levin S. S., Dobbins M. P. and Beers P.C. (1983) J. Liquid Chromat. 6, 179-192.

39. Berridge M. J., Dawson R. M., Downes C. P., Heslop J. P. and Irvine R. F. (1983) Biochem. J. 212, 473-482.

40. Jackowski S. and Rock C. O. (1989) Archs Biochem. Biophys. 268, 516-524.

41. Moritz A., De Graan P. N., Gispen W. H. and Wirtz K. W. (1992) J. biol. Chem. 267, 7207-7210.

42. Sagi-Eisenberg R. (1989) Trends Biochem. Sci. 14, 355-357.

43. Pagano R. E. and Longmuir K. J. (1985) J. biol. Chem. 260, 1909-1916.

44. Jones G. and Carpenter G. (1992) J. Cell. Biochem. Suppl. 16/B, 210.

45. Sato T., Hashizume T. and Fujii T. (1992) J. Biochem. (Tokyo) 112, 756-761.

46. Ryder N. S., Fisher G. J., Talwar H. S., Esmann J. and Voorhees J. J. (1989) J. Invest. Dermatol. 92, 511.

47. Kast R., Furstenberger G. and Marks F. (1991) Eur. J. Biochem. 202, 941-950.

48. Kroll M. H., Zavoico G. B. and Schafer A. I. (1989) J. Cell Physiol. 139, 558-564.

49. Kaszkin M., Richards J. and Kinzel V. (1992) Cancer Res. 52, 5627-5634. 